RESEARCH / REVIEW ARTICLE

\title{
MENGELOLA KEBIJAKAN SOSIAL DALAM REZIM PEMERINTAHAN KESEJAHTERAAN YANG SEDANG BERKEMBANG: APA YADANG DAPAT DIPELAJARI INDONESIA DARI PENGALAMAN KOREA SELATAN
}

\author{
Alfan Prahasta Adhisatya ${ }^{\bowtie}$ \\ Lembaga Konsultasi dan Bantuan Hukum Mahasiswa Islam, Surakarta, Jawa Tengah, Indoensia. \\ \alfanadhisatya@gmail.com
}

\begin{abstract}
Meskipun Indonesia dan Korea Selatan memiliki narasi paralel mengenai tatanan politik ekonomi mereka yang mempengaruhi pengaturan kesejahteraan sosial, mereka memiliki hasil kesejahteraan yang berbeda. Kegagalan pemerintahan kolaboratif di Indonesia yang member dampak bagi sistem distribusi kesejahteraan, yang mana warisan Orde Baru melanjutkan dan membatasi tradisi pemerintahan kolaboratif dalam pembuatan kebijakan sosial. Hal ini menjelaskan bagaimana warisan Orde Baru telah merusak sistem manajemen kesejahteraan yang ada di Indonesia dan berkontribusi pada hasil kesejahteraan yang rendah. Bentuk pemerintahan kolaboratif di Korea yang berfokus pada bagaimana tingkat tata kelola kolaboratif yang telah dipraktikkan di Korea yang telah terbukti berkontribusi pada peningkatan kesejahteraan sebagai jawaban bagaimana Korea mengelola konfigurasi kesejahteraan mereka.
\end{abstract}

Keywords: Tata kelola kolaboratif; Bentuk pemerintahan kolaboratif; Warisan Orde Baru; Kesejabteraan sosial.

\section{INTRODUCTION}

Tulisan ini mengulas kembali 'welfare governance' di Indonesia dan Korea Selatan yang selanjutnya disebut Korea. Dengan cenderung berfokus pada Indonesia, tujuan utama penelitian ini adalah untuk mensurvei kemungkinan Indonesia mengadopsi fiturfitur utama dari Korea yang dapat diterapkan untuk mengejar ketertinggalan dalam hal peningkatan hasil kesejahteraannya.

Pada dasarnya, artikel ini berusaha menjawab 2 (dua) pertanyaan: (1) Mengapa Indonesia tertinggal dalam pembangunan kesejahteraan sosial?; dan (2) Bagaimana Korea mengelola konfigurasi kesejahteraan mereka?.

Kegagalan pemerintahan kolaboratif di Indonesia yang member dampak bagi sistem distribusi kesejahteraan, yang mana warisan Orde Baru melanjutkan dan membatasi tradisi 
pemerintahan kolaboratif dalam pembuatan kebijakan sosial. Hal ini menjelaskan bagaimana warisan Orde Baru telah merusak sistem manajemen kesejahteraan yang ada di Indonesia dan berkontribusi pada hasil kesejahteraan yang rendah. Ini yang kemudian akan menjawab pertanyaan pertama di atas. Tulisan ini juga menjawab bentuk pemerintahan kolaboratif di Korea yang berfokus pada bagaimana tingkat tata kelola kolaboratif yang telah dipraktikkan di Korea yang telah terbukti berkontribusi pada peningkatan kesejahteraan sebagai jawaban bagaimana Korea mengelola konfigurasi kesejahteraan mereka.

Rezim kesejahteraan Indonesia dan Korea telah digambarkan sebagai 'produktif hingga tahun 1980-an dan 'inklusif-liberal' setelah dekade itu. Konsep kesejahteraan produktif digunakan untuk menggambarkan interaksi pertumbuhan ekonomi dan konfigurasi kesejahteraan sosial di Asia Timur. ${ }^{1}$ Pertentangan kunci dari konsep produktif adalah bahwa kebijakan sosial harus diposisikan di bawah pertumbuhan ekonomi, sedangkan negara secara aktif campur tangan dalam pembangunan ekonomi dan industrialisasi untuk mencapai pertumbuhan ekonomi yang tinggi. ${ }^{2}$

Bertepatan dengan pesatnya pertumbuhan ekonomi kedua negara, pada akhir 1970an, Korea dan Indonesia mulai fokus pada proses mendorong investasi dan mempertahankan pembangunan ekonomi. Pada periode ini, kebijakan investasi sosial tertentu, seperti pendidikan dan perawatan kesehatan, diperkenalkan secara besar-besaran untuk memastikan pasokan pekerja yang memadai yang dilengkapi dengan keterampilan dan pengetahuan yang diminta oleh pasar tenaga kerja. ${ }^{3}$ Mengenai hal ini, Kwon dan Kim memperkenalkan rezim baru yang muncul pada periode ini sebagai negara kesejahteraan pembangunan. 4

Setelah tahun 1990-an, demokratisasi dan liberalisasi ekonomi memicu reformasi kebijakan sosial. Reformasi ini telah mendorong mekanisme pasar ke inti penyediaan kesejahteraan, dan peran kebijakan bantuan sosial yang teruji kemampuan diperluas sebagai respons terhadap krisis ekonomi Kwon dan Kim. ${ }^{5}$ Di Indonesia, bantuan sosial diperkenalkan dalam bentuk perawatan kesehatan, program pekerjaan umum padat karya, beasiswa pendidikan, dan beras bersubsidi untuk masyarakat miskin. Namun, di Korea, pemerintah memperluas cakupan program bantuan publik yang ada, yang dikenal sebagai program Keamanan Mata Pencaharian Dasar Nasional (NBLS). Beberapa tunjangan tunai baru juga diberikan kepada individu berpenghasilan rendah dalam usia kerja dan keluarga mereka untuk jangka waktu terbatas. Setelah pemulihan dari krisis, rezim kesejahteraan di kedua negara sangat bergeser ke model inklusif-liberal. Model inklusif itu sendiri ditandai dengan munculnya ekspansi kebijakan kesejahteraan yang masif bagi sebagian penduduk

${ }^{1}$ Holliday, I. (2000). Kapitalisme Kesejahteraan Produktivis: Kebijakan Sosial di Asia Timur. Studi Politik 48(4): 706-723.

2 Goodin, R. (2001). Pekerjaan dan Kesejahteraan: Menuju Rezim Kesejahteraan Pasca-Produktivis. Jurnal Inggris Ilmu Politik. 30(1): 13-39.

${ }^{3}$ Croissant, A. (2004). Mengubah Rezim Kesejahteraan di Asia Timur dan Tenggara: Krisis, Perubahan, dan Tantangan. Kebijakan \& Administrasi Sosial. 38(5): 504-524.

${ }^{4}$ Kwon, H. dan W. Kim. (2015). Evolusi Transfer Tunai di Indonesia: Transfer Kebijakan dan Adaptasi Nasional. Studi Kebijakan Asia \& Pasifik. 2(2): 425-440.

${ }^{5}$ Ibid.

(c) Author(s). This work is licensed under a Creative Commons Attribution-NonCommercial-ShareAlike 4.0 International License. Published by Postgraduate Program, Master of Laws, Faculty of Law, Universitas Sebelas Maret, Indonesia 
yang tidak produktif (lansia, pengangguran, dan anak-anak) yang sebelumnya tersisih dari perluasan kesejahteraan. ${ }^{6}$

Kondisi ini menimbulkan pertanyaan kritis mengapa Korea dan Indonesia memiliki hasil kesejahteraan yang berbeda. Seperti yang telah kita ketahui, Korea memiliki prakondisi lintasan politik-ekonomi yang relatif sama dengan Indonesia sebagai negara berkembang yang telah mengalami perubahan bertahap dari model kesejahteraan produktif ke model yang lebih berorientasi pada kesejahteraan. Juga, kemerdekaan nasional Korea dan Indonesia dicapai pada waktu yang hampir bersamaan (masing-masing 15 Agustus 1945 dan 17 Agustus 1945).

Mengingat latar belakang tersebut, Korea relevan untuk dipilih sebagai panutan bagi Indonesia (dan negara-negara Asia lainnya), karena mewakili negara-negara Asia yang telah berhasil mengelola kebijakan sosial mereka dalam situasi 'di mana lembaga-lembaga demokrasi, di pengertian barat, masih belum sempurna', meskipun Korea dan Indonesia diklasifikasikan sebagai negara demokrasi. ${ }^{7}$ Berdasarkan konsep yang diperkenalkan oleh ahli teori ekonomi politik terkenal Chalmers Johnson, sebuah 'lembaga demokrasi yang belum sempurna' mengacu pada negara dengan rencana pembangunan-rasional, yang kontras dengan negara regulasi pasar-rasional di demokrasi Barat dan negara ideologis di negara sosialis. ${ }^{8}$

\section{METHOD}

Penelitian ini menggunakan pendekatan kualitatif untuk mengetahui bagaimana kualitas kesejahteraan sosial di Indonesia dan Korea serta melihat perkembangan dari masing-masing negara itu. Penelitian ini akan disiapkan dengan menggunakan jenis penelitian normatif, yaitu penelitian yang berfokus pada referensi kepustakaan dan dokumen. Studi ini menggunakan pendekatan konseptual (conceptual approach) dan pendekatan kasus (case approach). Pendekatan ini digunakan untuk mengetahui secara mendalam tentang semua yang berkaitan dengan isu penelitian. Dalam penelitian umumnya dibedakan antara data yang diperoleh langsung dari masyarakat dan dari bahan perpustakaan. Untuk mendapatkan data yang benar dan akurat dalam penelitian ini, prosedur yang diambil adalah studi literatur.

\section{RESULTS \& DISCUSSION}

\section{Kegagalan Tata Kelola Kolaboratif di Indonesia dan Bentuk Pemerintahan Kolaboratif di Korea}

Ketertinggalan Indonesia dalam pembangunan kesejahteraan sosial dapat dikatakan berasal dari kegagalan tata kelola kolaboratif di Indonesia yang berdampak bagi sistem

${ }^{6}$ Lin, K. dan CK Wong. (2013). Kebijakan Sosial dan Tatanan Sosial di Asia Timur: Pandangan Evolusioner. Jurnal Asia Pasifik Pekerjaan Sosial dan Pembangunan. 23(4): 270-784.

${ }^{7}$ Walker, A. dan CK Wong. (2005). Pengantar: Rezim Kesejahteraan Asia Timur. Bristol: Pers Polity. $2-$ 20.

${ }^{8}$ Heo, Y. and SH Lee. (2017). Laki-laki Tua atau Anak Baru di Kota? Warisan Negara Pembangunan di Reformasi Kesejahteraan Korea. Ulasan Studi Asia. 41(4): 647-663. 
distribusi kesejahteraan. Dikatakan bahwa kunci keberhasilan pengembangan kebijakan sosial terkait erat dengan kapasitas adaptif dan responsif lembaga politik yang ada dalam merespon perubahan global, yang mengarah pada model tata kelola kolaboratif dalam layanan kesejahteraan. Berkaitan dengan hal tersebut, dapat diasumsikan bahwa masalah kesejahteraan sosial, seperti pendidikan, kesehatan, dan kemiskinan, muncul karena tidak adanya tata kelola kolaboratif dalam proses pembuatan kebijakan. Tata kelola kolaboratif di sini mengacu pada keterlibatan secara luas kelompok-kelompok terkait dalam perumusan kebijakan, yang kemudian menghambat pengembangan dan hasil kebijakan sosial yang efektif, diikuti oleh hasil yang agak kabur.

Meskipun periode panjang kekuasaan otoriter di bawah rezim Orde Baru Presiden Soeharto secara resmi berakhir pada tahun 1998, pemerintahan Indonesia tetap terkait erat dengan politik patrimonial warisan Orde Baru, yang sangat ditandai dengan fitur-fitur seperti politik oligarki, korupsi yang merajalela, dan patronase. - hubungan klien dalam serangkaian konfigurasi barang publik. Situasi ini menghambat semangat reformasi yang sangat menekankan pemerintahan kolaboratif dalam pelayanan publik.

Sebagian besar pengamat percaya bahwa reformasi politik-ekonomi Indonesia pada tahun 1998 hanya merupakan respon reaktif terhadap kegagalan pemerintah otoriter di bawah Orde Baru Soeharto dalam mengatasi inflasi, dan tidak diikuti oleh basis masyarakat sipil yang tegas dan organisasi kelas pekerja yang kohesif.9 Ini memberi pemerintah kontrol yang lebih kecil, membuat demokrasi hanya berjalan di tingkat pemilihan daripada di tingkat yang substansial. Akibatnya, jalan Indonesia menuju pembangunan kesejahteraan sosial dengan kondisi-kondisi yang menguntungkan bagi perubahan-perubahan yang substansial dalam peningkatan kesejahteraan namun ditentukan oleh kepentingan sosial-politik oleh kelompok-kelompok yang bersangkutan.

Tidak seperti Korea Selatan, yang mana suara masyarakat sipil yang semakin tegas disuarakan untuk mendukung demokrasi, membongkar pemerintahan yang berpusat pada negara, sambil mengarah pada kolaborasi yang dinamis antara negara, organisasi nonpemerintah (LSM), dan bisnis. Dengan demikian, tidak mengherankan bahwa ketika gelombang transisi demokrasi dan globalisasi muncul di Korea, inisiatif kolaboratif yang lebih luas di dan setelah 1997 didirikan, meletakkan dasar bagi hubungan negaramasyarakat yang konstruktif dan membatasi hubungan patron-klien yang biasanya ditemukan di negara-negara dengan tingkat kemiskinan relatif tinggi, kelas menengah kecil, dan urbanisasi terbatas. ${ }^{10}$

Asal-usul sejarah pembangunan kesejahteraan sosial di Indonesia terbentuk pada masa rezim Orde Baru Soeharto. Sebagian besar kebijakan sosial diintegrasikan ke dalam program pengembangan masyarakat seperti program untuk desa tertinggal dan skema kredit mikro dalam pemerintahan yang sangat terpusat. Sementara itu, program jaminan sosial dibagikan kepada pegawai negeri sipil (TASPEN) dan militer (ASABRI) untuk mendapatkan dukungan dan loyalitas politik.

Sejak diberlakukannya kebijakan desentralisasi pada tahun 1999, inisiatif dan inovasi kebijakan sosial di Indonesia berkembang pesat, terutama di tingkat lokal. Beberapa

9 Fukuoka, Y. (2013). "Transisi Demokrasi Indonesia: Model Politik Klientelis. Tinjauan Kembali Demokratisasi. 20(6): 991-1013.

${ }^{10}$ Berenschot, W. (2018). The Political Economy of Clientelism: A Comparative Study of Patronage Indonesia. Studi Perbandingan Politik dan Demokrasi. 51(12): 93-1563.

(C) Author(s). This work is licensed under a Creative Commons Attribution-NonCommercial-ShareAlike 4.0 International License. Published by Postgraduate Program, Master of Laws, Faculty of Law, Universitas Sebelas Maret, Indonesia 
kebijakan sosial daerah yang populer - misalnya, Jaminan Kesehatan Jembrana di Bali, program kesehatan dan pendidikan gratis di Belitung Timur, kebijakan rumah sakit tanpa kelas di Kulon Progo - adalah salah satu contoh terkenal dari berbagai kebijakan sosial yang diprakarsai oleh pemerintah daerah. Sayangnya, implikasi kesejahteraan tetap kabur. ${ }^{11}$ Hal ini terjadi karena pemerintah daerah yang bertugas memberikan pelayanan sosial telah melihat peluang politik dalam penyediaan kesejahteraan mereka dan membentuk 'jaringan patronase dan klientelistik' dalam rangka meningkatkan dukungan rakyat untuk pemilihan umum.

Kondisi serupa juga terjadi di tingkat nasional. Beberapa bantuan tunai bersyarat unggulan seperti Program Nasional Pemberdayaan Masyarakat (PNPM Mandiri), Program Keluarga Sejahtera $(\mathrm{PKH})$, dan bantuan langsung tunai seperti Bantuan Langsung Tunai (BLT) dan Beras untuk Masyarakat Miskin (Raskin), menjadi titik balik dalam perkembangan kebijakan sosial di Indonesia. Khususnya, di bawah Presiden Yudhoyono, banyaknya program sosial tumbuh 'dari lima pada tahun 1998 menjadi lebih dari lima puluh pada tahun 2008, dengan banyak yang tersebar di semua kementerian. Selain itu, Indonesia juga telah memperluas cakupan jaminan sosial yang diselenggarakan di bawah Sistem Jaminan Sosial Nasional (SJSN), untuk seluruh masyarakat. ${ }^{12}$

Meskipun upaya untuk memperluas inisiatif perlindungan sosial skala besar telah dilakukan, hasil kesejahteraan dari inisiatif ini juga diragukan. Program bansos yang sangat pro-miskin ini dianggap sarat dengan intrik politik, digunakan oleh pemerintah untuk membangun loyalitas dan hubungan patron-klien, serta melakukan transaksi politik untuk menjaga stabilitas politik. Lebih lanjut bahwa ekspansi cepat bantuan sosial di bawah Yudhoyono bermotif politik untuk memberikan kekuasaan diskresi kepada menterinya atas pendanaan dan pengelolaan program perlindungan sosial. Anggaran perlindungan sosial ini mungkin juga menjadi sumber sumbangan bagi partai politik yang berafiliasi dengan menteri tertentu. ${ }^{13}$ Akibatnya, program bansos tidak terkoordinasi dengan baik dan tumpang tindih dalam proses penyalurannya. Situasi ini diperparah oleh kumpulan data penerima manfaat yang tidak akurat, sehingga melemahkan dalam mendorong kohesi sosial, yang mana akhirnya program bantuan sosial ini menciptakan konflik sosial dan melemahkan modal sosial di masyarakat.

Selain itu, perlu dicatat di sini bahwa penggambaran pemerintahan neopatrimonial dalam kebijakan kesejahteraan sosial kontemporer di Indonesia merupakan cerminan dari proses legislasi UU No. 11/2009 yang merupakan cetak biru sistem kesejahteraan sosial di Indonesia. Sebab, proses legislasi telah mengabaikan suara dan keterlibatan serikat pekerja, swasta, dan entitas publik lainnya selama proses perumusan. Undang-undang tersebut juga secara jelas menyatakan bahwa sistem penyelenggaraan kesejahteraan sosial diamanatkan oleh pemerintah untuk tetap mengontrol penyelenggaraan kesejahteraan sosial dalam hal perumusan kebijakan dan penyelenggara kesejahteraan. Sementara itu, aktor non-negara yaitu organisasi sosial dan masyarakat tidak didorong untuk memberikan kesejahteraan sosial.

${ }^{11}$ Masúdi, W. dan H. Hanif. (2011). Politik Kesejahteraan di Indonesia Kontemporer: Mengkaji Visi Kesejahteraan UU 11/2009. Kekuasaan, Konflik, dan Demokrasi. 3(2): 95-124.

12 McCarthy, J. dan M. Sumarto. (2018). Distributional Politics and Social Protection in Indonesia: Dilema Layering, Nesting, dan Social Fit dalam Kebijakan Kemiskinan Jokowi. Jurnal Ekonomi Asia Tenggara. 35(2): 223-236.

${ }^{13}$ Ibid.

(C) Author(s). This work is licensed under a Creative Commons Attribution 4.0 International License . Published by Postgraduate Program, Master of Laws, Faculty of Law, Universitas Sebelas Maret, Indonesia 
Sebuah studi oleh Masúdi dan Hanif ${ }^{14}$ menunjukkan bahwa undang-undang ini telah mengalami intervensi kepentingan politisi yang sebagian besar berafiliasi dengan lingkaran partai nasionalis (Partai Demokrasi Indonesia Perjuangan [PDIP], Golkar, dan Partai Demokrat). Mereka berpendapat keterlibatan organisasi non-negara tidak akan membawa keuntungan politik dalam hal politik elektoral. Sikap ini muncul karena mereka 'tidak memiliki jaringan organisasi sosial berbasis massa yang solid seperti halnya partai-partai Islam. Dengan demikian, secara politis jauh lebih menguntungkan bagi politisi untuk negara untuk memberikan kesejahteraan sosial secara langsung.

Sayangnya, selama lebih dari dua dekade setelah masa transisi demokratisasi, partaipartai nasionalis yang umumnya diasosiasikan dengan pandangan konservatif menguasai lembaga-lembaga utama negara, sehingga mempertahankan kendali atas sistem distribusi kesejahteraan sosial. Hal itu digambarkan oleh penerus Yudhoyono, Joko Widodo dari PDIP, yang berusaha agar dirinya terpilih dengan menggambarkan dirinya sebagai pemimpin populis, namun ternyata politik patrimonial tetap ada selama kepresidenannya. ${ }^{15}$ Untuk memperkuat platformnya sebagai pemimpin populis, pada tahun 2014, Jokowi memperkenalkan banyak program kesejahteraan baru yang secara fundamental tidak memiliki perbedaan substansial dari yang sudah ada. Misalnya, Kartu Indonesia Sehat (KIS) menjadi pengganti program sejenis (BPJS) sebelumnya dengan manfaat serupa. Namun, kepemimpinannya berubah pada akhir masa jabatan pertamanya (2014-2019) menjadi model yang tidak demokratis, dan bahkan dapat dikaitkan erat dengan imajinasi otoriter dengan cara yang lembut. Pernyataan ini ditegaskan oleh Power dalam kontribusi penting baru-baru ini di mana ia berpendapat bahwa 'pemerintahan Jokowi mengambil giliran otoriter pada tahun 2018, memanfaatkan lebih banyak institusi negara yang kuat - terutama instrumen penegakan hukum dan keamanan - untuk tujuan sempit dan partisan, termasuk penindasan oposisi demokratis yang sah secara konstitusional'. ${ }^{16}$ Upaya menghilangkan semangat demokratisasi dari masyarakat menunjukkan perlunya mempertanyakan nilai apa yang diajarkan sebagai demokratisasi Indonesia.

Beberapa penelitian telah mengakui Korea sebagai contoh praktik terbaik dalam memberikan tata kelola kolaboratif dalam konteks layanan kesejahteraan di Asia Timur karena dampaknya terhadap perluasan kebijakan kesejahteraan sosial (yang terintegrasi di bawah kebijakan pembangunan ekonomi). Hasil telah menunjukkan hasil yang luar biasa seperti penurunan kemiskinan dari 40,9 persen dari semua rumah tangga pada tahun 1965 menjadi 7,6 persen pada tahun 1991 yang membawa Korea keluar dari kemiskinan absolut. Selain itu, nilai Indeks Pembangunan Manusia Korea untuk tahun 2018 termasuk dalam kategori pembangunan manusia yang sangat tinggi, memposisikannya di 22 dari 189 negara - meningkat 24,5 persen dari 0,728 pada tahun 1990 menjadi 0,906 pada tahun 2018.

Pembangunan negara kesejahteraan Korea didorong oleh pertumbuhan ekonomi yang dikombinasikan dengan kolaborasi multi-stakeholder dalam proses pembangunan sejak pemerintahan otoriter Park Chung Hee, terutama pada tahun 1970-an ketika Korea

\footnotetext{
${ }^{14}$ Masúdi, W. dan H. Hanif. Op.cit.

15 Yuda, TK. (2019). Rezim Kesejahteraan dan Negara Patrimonial di Asia Kontemporer: Mengunjungi Kasus Indonesia. Jurnal Kebijakan Publik Asia. 12(3): 351-65.

${ }^{16}$ Power, PT. (2018). Giliran Otoritarian Jokowi dan Kemunduran Demokrasi Indonesia. Buletin Bahasa Indonesia Studi Ekonomi. 54(3): 307-338.
}

(c) Author(s). This work is licensed under a Creative Commons Attribution-NonCommercial-ShareAlike 4.0 International License. Published by Postgraduate Program, Master of Laws, Faculty of Law, Universitas Sebelas Maret, Indonesia 
mencapai pertumbuhan ekonomi progresif dengan menekankan industri kimia berat dan ekspor. Prioritas tinggi pemerintah adalah kebijakan industri, namun menghasilkan kesenjangan sosial antara standar hidup industri pedesaan dan perkotaan. Dengan ini, ketidakpuasan terhadap rezim Park meningkat di kalangan penduduk pedesaan dan menyebabkan penurunan legitimasi Park dalam pemilihan nasional 1969. Faktor-faktor ini akhirnya berkontribusi pada upaya rezim dalam meningkatkan standar hidup penduduk pedesaan dengan memperkenalkan Saemaul Undong gerakan yang dimulai pada pertengahan 1970-an. Hampir sama dengan yang terjadi di Indonesia. Pengenalan program untuk desa tertinggal (Inpres Desa Tertinggal - IDT) dan skema kredit mikro (Kredit Usaha Keluarga Sejahtera - KUKESRA) selama tahun 1970-an hingga 1980-an yang dirancang untuk membangun jaringan klientelistik terstruktur dari gubernur hingga kepala desa. Mereka bertugas menggerakkan warga desa untuk memilih pemerintahan otoriter Soeharto di setiap pemilihan presiden. ${ }^{17}$

Kerangka dasar dari Saemaul Undong adalah membangun kerjasama lintas elemen masyarakat, pemerintah, masyarakat, dan swasta, untuk mencapai tujuan bersama. Dalam pelaksanaannya, pemerintah mengalokasikan bantuan stimulus awal untuk pembangunan jalan desa, jembatan, gudang penyimpanan listrik, dan berbagai infrastruktur lain yang diperlukan untuk meningkatkan kesejahteraan dasar masyarakat berdaya. Selagi Saemaul Undong mulai berkembang di tingkat akar rumput, pemerintah mendorong Chaebol, konglomerat bisnis besar, untuk meningkatkan tingkat pendapatan penduduk pedesaan dengan menyediakan kesempatan kerja. Kolaborasi berkelanjutan antara pemerintah, masyarakat, dan Chaebol mendorong tingkat pertumbuhan ekonomi Korea di atas 9 persen dan menciptakan kondisi yang menguntungkan bagi perluasan kebijakan sosial.

Beberapa cendekiawan berpengaruh percaya Saemaul Undong adalah contoh yang baik dari tata kelola kolaboratif yang memberikan dasar untuk mencapai pembangunan berkelanjutan. Ini terutama karena fitur-fitur penting seperti pengembangan komunitas swadaya dan kemandirian serta peran Chaebol dalam menyediakan penciptaan lapangan kerja, yang berkontribusi pada kunci keberhasilan Korea untuk bertransformasi menjadi kekuatan global tingkat menengah setelah tahun 1990-an. ${ }^{18}$ Dari tahun 1965 hingga 1990an, ekonomi Korea tumbuh dengan tingkat pertumbuhan tahunan rata-rata GNP sekitar 10 persen. Hal ini mengubah perekonomian Korea Selatan menjadi hampir setara dengan Kongo pada tahun 1960 menjadi anggota Organization for Economic Co-operation and Development (OECD) dengan ekonomi terbesar ke-12 di dunia pada tahun 1996. ${ }^{19}$ Juga, menarik untuk dicatat bahwa meskipun program bantuan publik terbatas pada periode ini, kejadian kemiskinan di Korea secara drastis berkurang dari 40,9 persen dari semua rumah tangga pada tahun 1965 menjadi 9,8 persen pada tahun 1980 dan 7,6 persen pada tahun 1991.20

${ }^{17}$ Hadiz, V. dan Robison, R. (2017). Persaingan Populisme di Indonesia Pasca-Otoritarian. Internasional Ulasan Ilmu Politik. 38(4): 488-502.

${ }^{18}$ Lee, J. dan T. Kim. (2019). Sosial Politik Reformasi Kesejahteraan di Korea dan Jepang: Cara Baru Mobilisasi Sumber Daya. Sukarelawan. 30(1): 393-407.

${ }^{19}$ Minns, J. (2010). Miracles and Models: The Rise and Decline of the Developmental State in South Korea. Triwulanan Dunia Ketiga. 22(6): 1025-1043.

${ }^{20}$ Kwon, H. dan L. Yi. (2009). Pembangunan Ekonomi dan Pengurangan Kemiskinan di Korea: Pemerintahan Lembaga Multifungsi. Pengembangan dan Perubahan. 40(4): 769-792.

(C) Author(s). This work is licensed under a Creative Commons Attribution 4.0 International License . Published by Postgraduate Program, Master of Laws, Faculty of Law, Universitas Sebelas Maret, Indonesia 
Setelah Gerakan Gwangju, pemberontakan tahun 1980 dan gerakan demokrasi kedua tahun 1987 terjadi, Korea mulai memasuki 'masa transisi' dari pemerintahan otoriter menjadi negara yang lebih demokratis meskipun bentuknya belum sempurna. Banyak pengamat kebijakan sosial seperti Kwon mencatat bahwa proses dan perjuangan demokratisasi pada pertengahan 1980-an membawa kemajuan besar dalam menetapkan kebijakan kesejahteraan universal. Hal ini terutama karena proses demokratisasi membuka akses yang lebih luas bagi keterlibatan masyarakat sipil dan gerakan buruh dalam pembuatan kebijakan. ${ }^{21}$

Langkah definitif menuju pemerintahan kolaboratif dalam sistem kesejahteraan Korea diambil selama pemerintahan Kim Dae-Jung dan Roh Moo-Hyun. Menanggapi krisis ekonomi pada tahun 1997, pemerintahan Kim Dae-Jung segera membentuk Komisi Tripartit, yang mengkonsolidasikan perwakilan tenaga kerja, yang sebagian besar berasal dari Konfederasi Korea. Serikat Pekerja (KCTU) dan Federasi Serikat Pekerja Korea (FKTU), bisnis, masyarakat sipil, dan pemerintah untuk menyusun agenda reformasi kebijakan sosial di Korea. ${ }^{22}$ Pada tahun 1998, aliansi masyarakat pro-kesejahteraan yang terdiri dari lebih dari 20 organisasi sipil dan serikat pekerja mengajukan petisi untuk reformasi kesejahteraan total .23 Akibatnya, pemerintah Korea memperluas cakupan dan cakupan program bantuan publik yang ada, yang dikenal sebagai program NBLS.

Selain itu, Presiden Kim Dae-Jung melalui Kementerian Dalam Negeri dan Pemerintah menyatakan keinginan yang kuat untuk melaksanakan program-program layanan sosial yang dikontrakkan kepada LSM dan organisasi swasta, dalam rangka memperluas manfaat kesejahteraan untuk mencakup seluruh penduduk selama krisis. ${ }^{24}$ Tanggung jawab skema ini diamanatkan kepada sejumlah lembaga pemerintah sebagai pengawasan. Misalnya, di tingkat pusat, inisiatif mengontrakkan bakti sosial dikelola di bawah Kementerian Kesehatan dan Kesejahteraan, sedangkan Biro Urusan Perempuan dan Keluarga, Biro Kesehatan dan Kesejahteraan, dan Biro Swadaya masing-masing pemerintah daerah diberi mandat untuk mengawasi program di tingkat lokal. ${ }^{25}$

Pada awal 2000-an, Kim Dae-Jung memperkenalkan Manajemen Publik Baru (NPM) untuk mendorong perluasan kolaborasi dengan masyarakat sipil dan gerakan buruh dalam pembuatan kebijakan dengan menyediakan 'akses ke kursi di Majelis Nasional; karenanya mereka dapat membangun koalisi kebijakan dan memperluas organisasi mereka secara terbuka dan dapat menekan pemerintah pada isu-isu kebijakan individu'. ${ }^{26}$ Inisiatif yang semarak ini dibangun di bawah slogan 'kesejahteraan produktif. Ini mewakili visi negara kesejahteraan Korea yang didasarkan pada prinsip bahwa pengeluaran sosial harus ditujukan untuk mendukung produktivitas pasar. Hal ini terlihat dalam pengenalan kebijakan pengasuhan anak berupa daycare, paternity leave, dan maternity leave, yang kesemuanya diarahkan untuk mendukung rekonsiliasi pekerjaan - bagi keluarga berpenghasilan ganda.

${ }^{21}$ Kim, S. (2010). Tata Kelola Kolaboratif di Korea Selatan. Perspektif Asia. 34(3): 165-190.

${ }^{22} \mathrm{Ku}$, I. (2007). Reformasi Kesejahteraan Sosial Sejak Krisis Ekonomi 1997 di Korea: Prestasi, Keterbatasan, dan Prospek Masa Depan. Pekerjaan Sosial Asia \& Tinjauan Kebijakan. 1: 21-35.

${ }^{23}$ Lee, J. dan T. Kim. Op.Cit.

${ }^{24}$ Yuda, TK. Op.Cit.

${ }^{25}$ Kim, J. dan Y. Kaneko. (2011). Kontrak Layanan Sosial di Korea dan Jepang: Pemerintah Kota, Kontraktor Nirlaba, dan Penduduk Lokal. Jurnal Studi Kebijakan Korea. 26(1): 145-187.

${ }^{26} \mathrm{Heo}, \mathrm{Y}$. dan SH, Lee. Op.cit. 
Selain itu, pengenalan NPM juga memberikan kemungkinan yang lebih besar kepada swasta dan organisasi masyarakat sipil untuk mengambil bagian dalam memberikan pelayanan sosial. Implementasi NPM mendapat legitimasi karena Korea menghadapi krisis keuangan pada tahun 1998. Menariknya, kolaborasi berlanjut di era Roh Moo-Hyun dengan slogan 'kesejahteraan partisipatif, yang mana semangat desentralisasi, partisipasi, dan inovasi administrasi disorot sebagai tujuan kebijakan selama kepresidenannya. ${ }^{27}$

Meskipun inisiatif kesejahteraan produktif telah terbukti berhasil memenuhi permintaan tenaga kerja setelah krisis ekonomi, mereka menerima kritik pedas dari banyak pengamat karena mereka tidak memberikan perhatian holistik terhadap masalah ketenagakerjaan. Contoh penting dari hal ini adalah model pensiun redistributif terpadu kolaboratif yang diprotes oleh para penganggur yang tidak dapat membayar iuran penuh untuk program pensiun. Sayangnya, setelah hampir 10 tahun diimplementasikan, ide produktivitas kesejahteraan terbukti tidak berkelanjutan, terutama setelah partai konservatif-liberal mengambil alih setelah kepresidenan Roh berakhir.

Tata kelola kesejahteraan kolaboratif mengambil bentuk yang solid setelah kepemimpinan progresif Moon Jae-In berkuasa pada tahun 2017, menggantikan dua periode rezim konservatif Lee Myung Bak dan Park Khun Hee. Di bawah pemerintahan Moon, serikat pekerja mendapat posisi tawar yang menguntungkan dalam pembuatan kebijakan. Hal ini terlihat dari munculnya inisiatif kebijakan proworker yang bertujuan untuk mendorong full employment, perluasan lapangan kerja, dan peningkatan tunjangan kesejahteraan agar lebih dermawan mengikuti model Skandinavia. ${ }^{28}$ Anehnya, Presiden Moon Jae-In juga sekarang dalam posisi untuk memperkenalkan inisiatif kebijakan bagi pekerja Korea untuk bekerja lebih sedikit, sementara upah minimum akan dinaikkan sebagai cara untuk mengatasi masalah ketidakseimbangan pekerjaan - kehidupan yang mengarah pada tingkat kesuburan yang sangat rendah dan penundaan usia rata-rata untuk pernikahan pertama orang Korea (menjadi 30,1 tahun untuk wanita dan 32,8 tahun untuk pria di rentang waktu 1990-2016), yang semuanya menjadi masalah demografis yang serius di Korea kontemporer. ${ }^{29}$

Yang penting, penelitian kami menunjukkan bahwa kunci keberhasilan pemberian layanan sosial Korea adalah kemauan politik untuk menjadikan kerjasama sebagai bagian dari proses pembuatan kebijakan, terutama dengan masyarakat sipil dan serikat pekerja yang memiliki visi yang sama. ${ }^{30}$ Di bidang implementasi kebijakan, pemerintah Korea juga menyambut baik kerjasama dengan aktor non-negara dalam rangka mensinergikan tujuan inisiatif rezim kesejahteraan.

Ini memberikan penggambaran tentang pemerintahan kesejahteraan Korea yang didasarkan pada model kolaboratif yang telah dikonsolidasikan belakangan ini oleh kepemimpinan Kim Dae-Jung (1998- 2003), Roh Moo-Hyun (2003-2008), dan Moon Jae-In (2017-sekarang). Pola ini berbeda dengan Indonesia karena pendekatan tata kelola dalam pengembangan kebijakan sosial lebih didasarkan pada klientelisme dan korporatisme daripada demokrasi kemasyarakatan. ${ }^{31}$

${ }^{27}$ Kim, S. Op.Cit.

${ }^{28}$ Yuda, TK. Op.Cit.

${ }^{29}$ Baek. S., E. Sung, dan SH, Lee. (2011). Koordinat Saat Ini dari Rezim Perawatan Korea. Jurnal Perbandingan Kesejahteraan Sosial 27(2): 143-154.

${ }^{30}$ Yuda, TK. Op.Cit.

${ }^{31}$ Masúdi, W. dan H. Hanif. Op.Cit. 


\section{CONCLUSION}

Secara umum, kasus Korea mengingatkan kita pada argumen Acemoglu dan Robinson dalam kontribusi mereka tentang Mengapa Bangsa Gagal: Asal Usul Kekuasaan, Kemakmuran, dan Kemiskinan. Mereka berpendapat bahwa lembaga-lembaga politik terpusat mungkin dapat memberikan kesejahteraan sosial yang komprehensif dalam situasi di mana pertumbuhan ekonomi berada pada tingkat yang optimal. Sementara dalam situasi pertumbuhan ekonomi yang stagnan atau rendah, diperlukan kelembagaan yang inklusif untuk mendorong inovasi kesejahteraan dan mendorong pertumbuhan pembangunan yang berkelanjutan. Artikel ini telah menunjukkan bahwa begitu pertumbuhan ekonomi melambat selama periode pasca krisis ekonomi, Korea Selatan segera mereformasi manajemen kesejahteraan mereka dengan memperluas sistem kolaborasi non-negara ke arah yang lebih inklusif. Sementara itu, sebaliknya, kolaborasi Indonesia yang ada dalam pengaturan kesejahteraan masih terbatas dan keputusan kebijakan yang cenderung terpusat.

Dari analisis ringkas sebelumnya, kami menemukan bahwa tradisi pemerintahan kolaboratif yang lemah dalam pembangunan kesejahteraan Indonesia dapat dikaitkan dengan kegagalan pembangunan ekonomi pemerintahan otoriter Soeharto di masa lalu atau dalam memfasilitasi pertumbuhan masyarakat sipil yang asertif. Hal ini memberikan kontrol yang lebih kecil kepada pemerintah dan pada akhirnya menjadi lahan subur bagi kelangsungan pemerintahan patrimonial Orde Baru dalam mode baru di era demokrasi. Menariknya, sebagaimana dijelaskan sebelumnya, bahkan legislasi Visi Kesejahteraan UU 11/2009 yang merupakan cetak biru pembangunan sistem kesejahteraan Indonesia, sengaja dirancang untuk menghilangkan otoritas aktor non-negara dalam distribusi pelayanan sosial. Pertimbangan utama adalah pragmatisme politik yang menguntungkan 'politisi konservatif' selama periode pemilu jika kesejahteraan sosial langsung disalurkan ke kelompok sasaran.

Sebaliknya, Korea Selatan memberikan model negara Asia Timur di kawasan yang relatif berhasil mengembangkan berbagai kebijakan sosial yang berlabuh pada masyarakat sipil dan mekanisme tripartit yang serupa dengan Eropa meskipun bentuknya belum sempurna. Asumsinya bahwa latar belakang sejarah ini telah meletakkan dasar bagi hubungan dan kolaborasi negara-masyarakat yang konstruktif dan pada akhirnya membatasi praktik patronklien dalam proses distribusi kesejahteraan. 


\section{REFERENCES}

Baek. S., E. Sung, dan SH, Lee. (2011). Koordinat Saat Ini dari Rezim Perawatan Korea. Jurnal Perbandingan Kesejabteraan Sosial 27(2): 143-154.

Berenschot, W. (2018). The Political Economy of Clientelism: A Comparative Study of Patronage Indonesia. Studi Perbandingan Politik dan Demokrasi. 51(12): 93-1563.

Croissant, A. (2004). Mengubah Rezim Kesejahteraan di Asia Timur dan Tenggara: Krisis, Perubahan, dan Tantangan. Kebijakan \& Administrasi Sosial. 38(5): 504-524.

Fukuoka, Y. (2013). “Transisi Demokrasi Indonesia: Model Politik Klientelis. Tinjauan Kembali Demokratisasi. 20(6): 991-1013.

Goodin, R. (2001). Pekerjaan dan Kesejahteraan: Menuju Rezim Kesejahteraan PascaProduktivis. Jurnal Inggris Ilmu Politik. 30(1): 13-39.

Hadiz, V. dan Robison, R. (2017). Persaingan Populisme di Indonesia Pasca-Otoritarian. Internasional Ulasan Ilmu Politik. 38(4): 488-502.

Heo, Y. and SH, Lee. (2017). Laki-laki Tua atau Anak Baru di Kota? Warisan Negara Pembangunan di Reformasi Kesejahteraan Korea. Ulasan Studi Asia. 41(4): 647-663.

Holliday, I. (2000). Kapitalisme Kesejahteraan Produktivis: Kebijakan Sosial di Asia Timur. Studi Politik 48(4): 706-723.

Kim, J. dan Y. Kaneko. (2011). Kontrak Layanan Sosial di Korea dan Jepang: Pemerintah Kota, Kontraktor Nirlaba, dan Penduduk Lokal. Jurnal Studi Kebijakan Korea. 26(1): 145-187.

Kim, S. (2010). Tata Kelola Kolaboratif di Korea Selatan. Perspektif Asia. 34(3): 165-190.

Ku, I. (2007). Reformasi Kesejahteraan Sosial Sejak Krisis Ekonomi 1997 di Korea: Prestasi, Keterbatasan, dan Prospek Masa Depan. Pekerjaan Sosial Asia \& Tinjanan Kebijakan. 1: 2135.

Kwon, H. dan L. Yi. (2009). Pembangunan Ekonomi dan Pengurangan Kemiskinan di Korea: Pemerintahan Lembaga Multifungsi. Pengembangan dan Perubahan. 40(4): 769-792.

Kwon, H. dan W. Kim. (2015). Evolusi Transfer Tunai di Indonesia: Transfer Kebijakan dan Adaptasi Nasional. Studi Kebijakan Asia \& Pasifik. 2(2): 425-440.

Lee, J. dan T. Kim. (2019). Sosial Politik Reformasi Kesejahteraan di Korea dan Jepang: Cara Baru Mobilisasi Sumber Daya. Sukarelawan. 30(1): 393-407.

Lin, K. dan CK Wong. (2013). Kebijakan Sosial dan Tatanan Sosial di Asia Timur: Pandangan Evolusioner. Jurnal Asia Pasifik Pekerjaan Sosial dan Pembangunan. 23(4): 270-784.

Masúdi, W. dan H. Hanif. (2011). Politik Kesejahteraan di Indonesia Kontemporer: Mengkaji Visi Kesejahteraan UU 11/2009. Kekuasaan, Konflik, dan Demokrasi. 3(2): 95-124.

McCarthy, J. dan M. Sumarto. (2018). Distributional Politics and Social Protection in Indonesia: Dilema Layering, Nesting, dan Social Fit dalam Kebijakan Kemiskinan Jokowi. Jurnal Ekonomi Asia Tenggara. 35(2): 223-236.

Minns, J. (2010). Miracles and Models: The Rise and Decline of the Developmental State in South Korea. Trimulanan Dunia Ketiga. 22(6): 1025-1043.

Power, PT. (2018). Giliran Otoritarian Jokowi dan Kemunduran Demokrasi Indonesia. Buletin Bahasa Indonesia Studi Ekonomi. 54(3): 307-338.

Walker, A. dan CK Wong. (2005). Pengantar: Rezim Kesejahteraan Asia Timur. Bristol: Pers Polity. $2-20$.

Yuda, TK. (2019). Rezim Kesejahteraan dan Negara Patrimonial di Asia Kontemporer: Mengunjungi Kasus Indonesia. Jurnal Kebijakan Publik. Asia. 12(3): 351-65.

(C) Author(s). This work is licensed under a Creative Commons Attribution 4.0 International License . Published by Postgraduate Program, Master of Laws, Faculty of Law, Universitas Sebelas Maret, Indonesia 